\title{
Fears from a medical student part II: Prepping the patient
}

Veins replete with burning medicine, his eyes shiver shut. Is it quite the same to call this sleep? He's surrounded by masks, whispering and weaving, cleansing his arms, piercing taut skin. A catheter slithers into the anatomical pouch as the soft roar of razor denudes his abdomen. The tape recruits every last hair. Paintbrush to belly button, spreading orange chlorhexidine across the impact line.

The man we know is gone, and in his placenine square inches of skin framed by tape and sheets. The overhead lights turn on. "Time out!" All look up for a moment and nod,

to show no wrong. To acknowledge the tissue that was once our patient.

My face turns to the side.

We inhale the smell of seared flesh through our masks.

\section{Arpan V Prabhu, Ahmed Kashkoush}

University of Pittsburgh School of Medicine, Pittsburgh, PA, United States

Correspondence to Arpan V Prabhu, University of Pittsburgh School of Medicine, 518 Scaife Hall, 3550 Terrace Street, Pittsburgh, PA 15261, United States; prabhuav2@upmc.edu

Note This poem is part of a series of medical student perspectives in medical school, with the first poem entitled, "Fears from a medical student" (also published in Medical Humanities), which focused on the difficulty of end-of-life conversations.

Competing interests None declared.

Provenance and peer review Not commissioned; internally peer reviewed.

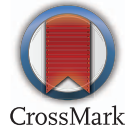

To cite Prabhu AV, Kashkoush A. Med Humanit 2017:43:e9.

Published Online First 5 December 2016

Med Humanit 2017;43:e9. doi:10.1136/medhum-2016-011120 